\title{
Da'wa Model Based on Brand Community Value: Qaryah Thayibah Implementation for Villages Fostered by 'Aisyiyah Ponorogo
}

doi.org/10.18196/afkaruna.v17i2.10225

\section{Imroatul Istiqomah}

Fakultas Ushuluddin Universitas Darussalam Gontor Ponorogo

imroatul.istiqomah@unida.gontor.ac.id

\section{Maria Ulfa}

Fakultas Ushuluddin Universitas Darussalam Gontor Ponorogo mariaulfa@unida.gontor.ac.id

\begin{abstract}
Islamic da'wa's performance is highly influenced by the techniques and tactics used in conjunction with the preaching object. 'Aisyiyah applies a Qoryah Thayyibah group-based da'wa model that is expected to become the Brand Community Value. Each Regional Leader must enforce this program with a minimum of three supported villages. The purpose of Qoryah Thayyibah, in general, is to establish an advanced and dignified Islamic society. This study aimed to identify the implementation of the Qoryah Thayyibah program and the obstacles faced by 'Aisyiyah Ponorogo. The qualitative literary approach was used in this analysis. Accordingly, the data collection was through documentation (identification of documents), observation, and interviews. The inductive reasoning was also used in the analysis to see how the Qoryah Thayyibah program is implemented, and the conclusion was taken from the general statement to a particular statement. The primary sources were the results of interviews with the management of 'Aisyiyah Ponorogo, interviews with Qoryah Thayyibah PW East Java and PDA Ponorogo, the results of Tanwir relevant to Qoryah Thayyibah and supported by other sources, such as articles, documents or writings on the official PDA website of 'Aisyiyah Ponorogo. 'Aisyiyah Ponorogo has successfully applied the Qoryah Thayyibah in five of the eight intended fields. They faced
\end{abstract}


obstacles in several fields, including spirituality, education, economics, and health.

Keywords: 'Aisyiyah, Qoryah Thayyibah, Da'wa, Women Movement

\section{ABSTRAK}

Keberhasilan dakwah Islam sangat dipengaruhi oleh metode dan strategi yang digunakan sesuai dengan objek dakwahnya. 'Aisyiyah memiliki model dakwah berbasis masyarakat Qoryah Thayyibah yang diharapkan menjadi Brand Community Value. Program ini wajib dilaksanakan oleh setiap Pimpinan Wilayahnya dengan batas minimal tiga desa binaan tiap daerah. Tujuan Qoryah Thayyibah secara umum adalah untuk mewujudkan masyarakat Islam yang maju dan bermartabat. Penelitian ini bertujuan untuk mengetahui implementasi program Qoryah Thayyibah desa binaan 'Aisyiyah Ponorogo dan kendala-kendala yang dihadapi. Metode yang digunakan dalam penelitian ini adalah metode literer kualitatif. Teknik pengumpulan data adalah dokumentasi (identifikasi dokumen), observasi dan wawancara. Metode analisis yang digunakan adalah induktif. Metode Induksi untuk melihat implementasi program Qoryah Thayyibah hingga ditarik suatu kesimpulan dari pernyataan umum menjadi pernyataan yang sifatnya khusus. Sumber utamanya adalah hasil wawancara pengurus 'Aisyiyah Ponorogo,wawancara pengurus Qoryah Thayyibah PW Jatim dan PDA Ponorogo, hasil Tanwir berkaitan dengan Qoryah Thayyibah dan didukung sumber-sumber lain seperti jurnal, dokumen-dokumen, atau tulisan-tulisan di web resmi PDA 'Aisyiyah Ponorogo. Hasil dari penelitian ini ditemukan bahwa 'Aisyiyah Ponorogo telah berhasil mengimplementasikan program Qoryah Thayyibah dalam lima bidang dari jumlah keseluruhan delapan bidang garap. Kendala-kendala yang mereka hadapi berada di beberapa bidang diantaranya bidang kerohanian, pendidikan, ekonomi dan kesehatan.

Kata Kunci: 'Aisyiyah, Qoryah Thayyibah, Dakwah, Gerakan Wanita

\section{INTRODUCTION}

Islamic da'wa is split into individuals and organizations or movements. Every Islamic religious institution is, in essence, a da'wa institution because the purpose of those institutions is to preach Islam, to facilitate the consolidation of movements and to equalize perceptions. Indirectly, in addition to their primary function as centers of social information, these institutions are also centers of political communication. Ulama are required to be able, when conflicts occur, to bridge religious orders with cultural and social realities. This ability is how religious beliefs and 
provisions can be articulated by the figure of a cleric in various practical events (social change). ${ }^{1}$

Jurgen Habermas argues that da'wa is a medium that can help people achieve autonomy and maturity in thinking and acting to transform emancipatory theory. Meanwhile, in a deconstructive-constructive way, Michael Foucault implies that da'wa is knowledge of strategic conversations. Da'wa is not only understood as a transformation of value that appears as a top-down structural arrangement (between the da'i and the preached) but dialectically forms a functional relationship with the pattern strategy and style of delivery. ${ }^{2}$ The Islamic da'wa's epistemological dimension can be seen through the following chart:

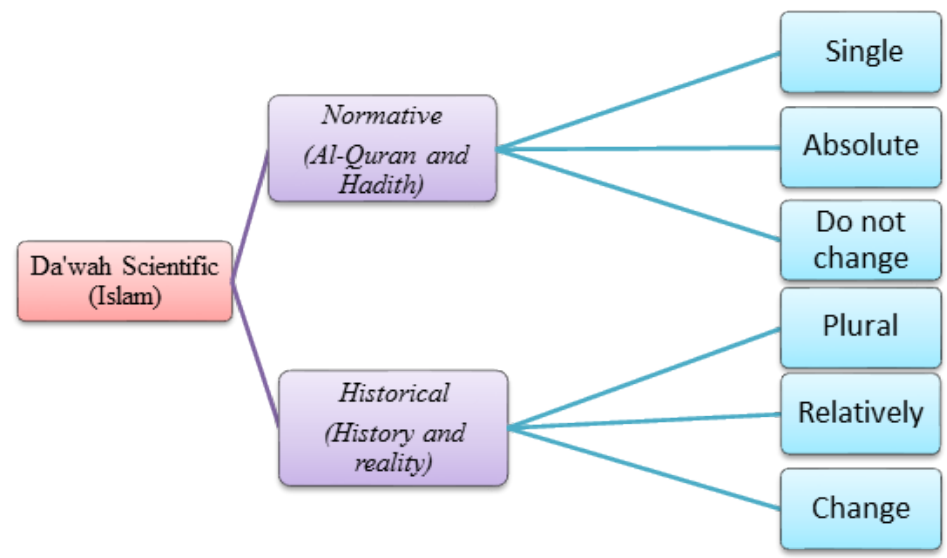

Diagram 1. Islamic Da'wa's Epistemological Dimension³

'Aisyiyah is the oldest socio-religious organization with a strong socio-religious character that has now developed into a modern women's movement. It was Kyai Haji Ahmad Dahlan and his wife who instilled the basic character of the Aisyiyah movement. Both of them educate daughters of Muhammadiyah who are still in their teens to understand religious knowledge and how to care for and serve the broader community. The most significant contributions of 'Aisyiyah to improve Indonesia, in general, are in the fields of education and health. It does not mean, however, that 'Aisyiyah only restricts its movements in these two fields. 'Aisyiyah also plays an increasingly vital role in reacting to the rise of global problems, both on the global women's movement agenda and general issues in other modern civilizations. ${ }^{4}$ 
Aisyiyah, founded in 1917, played an important role in the rise of Indonesian women. The 'Aisyiyah movement has occupied an important position in the history of the women's movement in Indonesia for almost a century. Long before the First Women's Congress was successfully held at Pendopo Joyodipuran, Mataram (Yogyakarta) on December 22-25, 1928. 'Aisyiyah progressively transforms into a modern Islamic women's organization.

'Aisyiyah seeks to empower females. Women's empowerment is an attempt to allow them to gain access to and influence over wealth, economy, politics, community, and culture so that they can organize themselves and increase self-confidence. This self-confidence enables women to engage in problem-solving to improve their skills and self-concept actively. ${ }^{6}$

'Aisyiyah also develops different community-based activities, particularly in increasing community life awareness. It becomes significant since 'Aisyiyah recognizes the importance of Islam having a strong presence not just for private matters but also for the public. A Muslim is not only expected to be successful in a private or personal sphere but also consciously form the culture or country in which they live by applying Islamic practices. 'Aisyiyah is a Muslimah movement that emphasizes self-discipline in order to improve individual piety and regulate public piety. One of the programs is Qoryah Thayyibah, which generally aims to create an advanced and dignified Islamic society. In particular, this program aims to facilitate the integration of "amar ma'ruf nahi munkar" movement, through assemblies, from all elements within the Muhammadiyah and 'Aisyiyah. The goal of Qoryah Thayyibah is the physical and mental development of strong community groups, creating a healthy, peaceful and prosperous community environment, and realizing the community's al-ma'un da'wa movement. ${ }^{7}$

Qoryah Thayyibah is expected to become the brand community value for the targeted community. The Qoryah Thayyibah program, tested since 1989, has been applied to 'Aisyiyah regional leaders all over Indonesia. The main objective of this program is to become 'Aisyiyah's priority program to empower the community so that every village or group 
adhere to the Islamic teachings, both in relation to Allah SWT (hablun minallah) and human relations (hablun minannas) in all aspects life to create an advanced and dignified Islamic society. ${ }^{8}$

The main goal of this research was to identify the implementation of the 'Aisyiyah da'wa model based on the development of Qoryah Thayyibah. The steps, materials, methods, strategies and media for da'wa, stated as the research results are expected to become a basic reference for 'Aisyiyah Ponorogo in particular or other Muslim women's organizations in general.

Consequently, a previous study related to this research topic was found entitled 'The Organizational Role of Aisyiyah among Members in Creating Sakinah Families' written by Ismah Salman from the Women's Studies program at Universitas Indonesia in 1995. This descriptive study explained the steps taken by 'Aisyiyah among members in developing and creating a sakinah family. According to the guidance of the Al-Qur'an and the Sunnah, these steps are essential for restoring the role of family members where everyone must understand their respective roles. Because of their critical role in the family, women must be able to improve their performance. In creating a sakinah family, 'Aisyiyah emphasizes the five directions, formal and non-formal education, enhancing entrepreneurial skills and cooperatives, realizing Qoryah Thayyibah, and improving the family economy. In addition, by improving the well-being of mothers and children, 'Aisyiyah also builds relationships with the wider community and publishes relevant guidebooks and guidelines that are helpful to the community. This research, however, was limited to 'Aisyiyah's steps in realizing the sakinah family and did not discuss 'Aisyiyah's roles in other fields, such as politics and da'wa.

In comparison, 'the struggle of Nyai Ahmad Dahlan to improve the role and position of women in 1914-1946 through 'Aisyiyah,' found at Universitas Indonesia, Faculty of Cultural Sciences, by Retno Wuryaningtyas in 1999 narrated the role and struggle of Nyai Ahmad Dahlan in increasing the role and position of women in Kauman through the 'Aisyiyah movement in 1914-1946 in the form of historical research with a biographical nature. This movement came out of the Sopo Tresno 
association due to $\mathrm{KH}$ educating women in their teens. It also exposed religious science and the challenges of the people of that era, especially for Ahmad Dahlan and his wife. This research focused on Nyai Ahmad Dahlan's personal role and did not discuss the 'Aisyiyah organization's role in general.

Another study, 'Aisyiyah Malang Regional Organization 1968-1995 Research on the Women's Movement,' was compiled in 2010 by Nur Laili Rohmah at Malang State University, Historical Science Program. This historical research is bibliographical, discussing the two steps, the role and progress of 'Aisyiyah in Malang from 1968 to 1995. Firstly, through the charitable efforts of the organization to increase knowledge of Islam, including the establishment of schools, hospitals, orphanages and cooperatives. Second, by setting up a women's prayer room, Jamiatul Ummahat, Rukun Kebahagiaan Wanita (RKW) and pioneering the establishment of the Association of Indonesian Women's Organisations (GOWI) for movements outside charitable organizations. This research focused on discussions in the Malang area from 1968 to 1995, and did not discuss the role of the 'Aisyiyah organization in general.

Accordingly, 'the effectiveness of the Tabligh 'Aisyiyah Council Study in improving the Community's religious understanding' was written by Rahmi Damis in 2012 in Al-Fikr journal, volume 16, number 2. It was field research with a qualitative descriptive method held at Makassar. This study concluded that Al-Qur'an and al-Hadist, AD/ART and Tanfidz Musywil are the basis for the implementation of the dialogical da'wa carried out by the South Sulawesi Tabligh 'Aisyiyah Council, which describes the da'wa program of 'Aisyiyah. The dialogic method was applied, while the time and material were quite efficient, and the participants varied. Therefore, these variables really promote the increase in the community's religious understanding.

\section{RESEARCH METHOD}

Qualitative literary methodology or literature research was applied in this study. The qualitative method was intended to sharpen the findings. A qualitative technique for analyzing the da'wa strategies was carried out 
in Qoryah Thayyibah program by 'Aisyiyah Ponorogo.

Based on the method used in this study, the information was categorized accordingly. The primary data source was obtained from interviews with the actors of the Qoryah Thayyibah program supported by written data in the form of manuals, journals, magazines, research results, and congress decisions directly published by 'Aisyiyah. The data collection was through documentation (identification of documents), observation, and interviews. The inductive analytical method was used in the analysis to see how the Qoryah Thayyibah program is implemented. Also, the induction method before a conclusion was drawn from a general statement to a particular statement.

The purpose of the validity test was to check the validity or truth of the reported data against the factual data in the field. In qualitative research, there are four data validity tests, including credibility, transferability, dependability and confirmability. This study measured transferability and dependability. The implementation of the Qaryah Thoyyibah program by 'Aisyiyah Ponorogo was explained in detail for a clear research context and focus. The conclusions were taken from the overall exposure.

\section{DISCUSSION}

Below is the ideal basis for the Qoryah Thayyibah program:

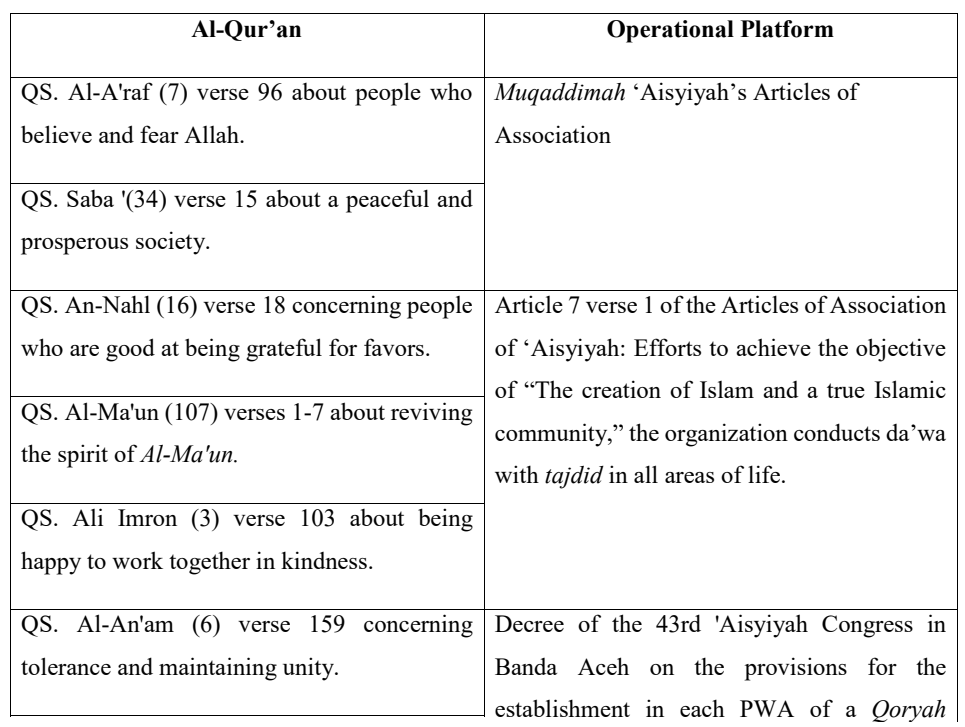




\begin{tabular}{|c|c|}
\hline $\begin{array}{l}\text { QS. Shaf (61) verse } 4 \text { about the congregation } \\
\text { such as shaf / line in prayer. }\end{array}$ & \multirow[t]{3}{*}{$\begin{array}{l}\text { Thayyibah Assisted Village, at least one target } \\
\text { village. }\end{array}$} \\
\hline $\begin{array}{l}\text { QS. Ali-Imron (3) verse } 110 \text { concerning the } \\
\text { spirit of amar makruf nahi munkar. }\end{array}$ & \\
\hline $\begin{array}{l}\text { QS. Ar-Rum (30) verse } 21 \text { concerning the } \\
\text { households of the people who are sakinah } \\
\text { mawaddah warohmah. }\end{array}$ & \\
\hline $\begin{array}{l}\text { QS. Ar-Ra'd (13) verse } 11 \text { about citizens who } \\
\text { have a high work ethic. }\end{array}$ & \multirow{2}{*}{$\begin{array}{l}\text { The decision of the Tanwir I 'Aisyiyah Session } \\
\text { in Samarinda in July } 2007 \text { for the period 2005- } \\
2020 \text {. }\end{array}$} \\
\hline $\begin{array}{l}\text { QS. Yunus (10) verse } 5 \text { discusses the } \\
\text { significance of education and attempts to } \\
\text { make it happen. }\end{array}$ & \\
\hline
\end{tabular}

Table 1. The ideal basis for the Qoryah Thayyibah program

The focus of Qoryah Thayyibah is based on the potential and critical issues faced by the target villages, such as spirituality, economics, education, social affairs, health and environment, politics and law, communication and information technology, as well as other fields in line with local circumstances. ${ }^{9}$

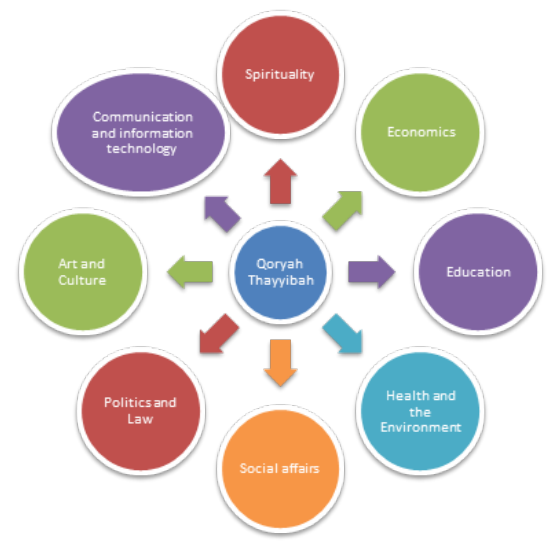

Graph 2. Qoryah Thayyibah's Field of Work

'Aisyiyah Ponorogo selected three main areas in implementing the Qoryah Thayyibah program in Ponorogo District, Siman District and Sawo District, which consisted of 12 target villages. Each sub-district has a village as the pilot project of this program. The main person in charge of 
Qoryah Thayyibah was the Ponorogo Regional Leader (PDA), Hj. Titi Listyorini, S.H, while the deputy head of the program was the head of the health sector, Hj. Siti Khoirul Djannah.

Per several criteria under several considerations, target villages were selected, especially villages that are not yet developed and not too backward. Second, the village did not yet have an 'Aisyiyah branch. Third, the religious understanding was still lacking in most of the village community, and some even became a mission area for Christianization. The factors underlying these three criteria were that 'Aisyiyah can advance the village in multiple fields, including religion, education, economics and social conditions. In the meantime, it is hoped that it will become a new branch as a structural da'wa target for villages where 'Aisyiyah does not yet have a branch (the aim is to facilitate the coordination, monitoring and evaluation of other 'Aisyiyah programs structurally). The third consideration was that the majority of the population did not understand Islam or Christian mission areas, and it was hoped that 'Aisyiyah could strengthen their spirituality and aqidah. ${ }^{10}$

Given that 'Aisyiyah is a Muslim organization, female Muslims have become the main focus of the Qoryah Thayyibah movement. The number of members from each assisted village is 25 mothers with childbearing age criteria, having a child, low economy, low education and housewives. Many things are provided, ranging from increasing knowledge of religion, skills, household management, increasing awareness of hygiene and health, and so on. In detail, based on the findings of the interview and other written sources, the implementation of the Qoryah Thayyibah 'Aisyiyah Ponorogo program"1 is as follows:

\section{Spirituality}

The spiritual field of Qaryah Thayyibah by 'Aisyiyah Ponorogo is to make members aware of the importance of fostering congregations and prospering the mosque as a center of worship, education and community development. Second, to turn on the recitation regularly to increase religious knowledge and close friendship. Third, encourage members to perform sunnah worship (Rawatib prayer, midnight prayer, fasting 
Monday, Thursday and others). Fourth, educating members to be able to manage zakat, infaq and shadaqah. Fifth, mobilizing the community to perform the haj pilgrimage. Sixth, cooperating with the local radio as a means of oral preaching delivered by the muballighat 'Aisyiyah, which contains tausiyah diniyah regarding human relations with God, human relations with family, neighbor and the environment and so on. Seventh, efforts to convert non-Muslim women and assist their converting process. $^{12}$

\section{Economy}

Economic sector by increasing cooperation for the procurement of business capital. Second, increasing the cooperation of community members in various fields to develop businesses. Third, build an entrepreneurial spirit with productive skills training. Fourth, instill a frugal and non-consumptive life.

Skills training to increase members' economic income is carried out in several forms of training that are suitable for women's skills. The training that has been carried out is training on making Shibori batik, sewing training, training on making trasi crackers, various wet and dry cakes and making dumplings. In addition to training, members are taught entrepreneurship that can be a source of economy, such as catfish farming, growing hydroponic plants and so on.

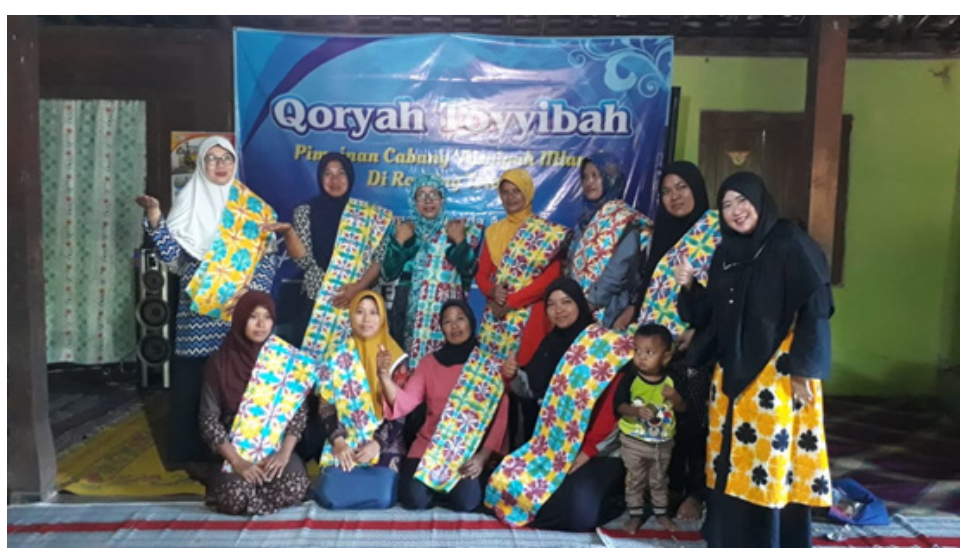

Picture 1. Shibori Batik Training Activities 


\section{Education Sector}

In the education sector, the program focuses on freeing members of Arabic, Latin, and Bahasa Indonesia illiteracy. Second, it tries to make the members aware of the importance of education for their children to improve their quality of life. Third, 'Aisyiyah strives to have a public reading garden as a source of basic literacy for the community. Fourth, the program also strives to foster children programs through educational funding assistance for underprivileged children. Fifth, the organization directs the public to take equivalency examinations $A, B$ or $C$ for those who do not have an official certificate.

\section{Health and Environment}

In the health sector, it is done by mobilizing the community to reduce the Maternal Mortality Rate (MMR), Infant Mortality Rate (IMR) and the Mother Care Movement (GSI), as well as the Inter-Guard Ready Movement (SIAGA). Second, a team is formed for disseminating a clean and healthy environment and loves greenery. Third, society is encouraged to have a healthy prayer room. Fourth, the program organizes reproductive health consultation bureaus/posts. Fifth, it also reactivates the Health Information and Consultation Center, as well as Family Sakinah (PIKSA).

For example, PCA Siman, Ronowijayan and Brahu branches held health education in collaboration with local health center health workers, medical staff at 'Aisyiyah Ponorogo Hospital on maternal and child health and BSE practice. The next stage is about the female reproductive system and the risk of cervical cancer and its prevention. PCA Ponorogo and Sawo sub-districts conducted counseling on obstetric health, family planning and immunization in collaboration with practical midwives and BKKBN. At the Qoryah Thayyibah management level, training for reproductive health cadres was held at 'Aisyiyah Ponorogo Hospital. ${ }^{13}$

In the field of environmental preservation, 'Aisyiyah encourages Qoryah Thayyibah members to cultivate a clean life, good for themselves, homes, food and the environment. This is a strategic effort considering that a mother is Rabbatu al-Bait, who is fully responsible for food, house 
hygiene and its surroundings. Furthermore, they are encouraged to plant medicinal plants to maintain health, such as ginger, turmeric, galangal and so on.

\section{Social Field}

In the social sector, it is done by making people aware of upholding the principles of ta'awun. Second, the program encourages the movement of foster parents. Third, it tries to increase community members' awareness about the rampant trafficking of children and women.

'Aisyiyah Ponorogo held Social Ta'awun in various ways, including the assistance of basic necessities to Qoryah Thayyibah participants, which was distributed along with recitation, counseling and training events. Another way is to support orphans and help the needy.

Especially during the Covid 19 pandemic, 'Aisyiyah is promoting social ta'awun at various management levels in collaboration with the Muhammadiyah Covid-19 Command Center Ponorogo, Lazismu Ponorogo held Social Ta'awun for PAUD and TK ABA teachers' Aisyiyah at 23 PCA. In cooperation with PT. Charoen Pokphand Indonesia donated 10,000 eggs for Pesantren 'Aisyiyah Ponorogo. In collaboration with Lazismu, distributed 1050 basic food packages to members of the Qoryah Thayyibah program and 385 special packages for pregnant women.

Most recently, PDA Ponorogo held the Launching of Griya Lansia Sakinah on November 1, 2020. Previously, it was named Geriartri 'Aisyiyah, which consisted of 70 elderly mothers who have been established since 2007. The activities they hold are recitation, prayer and $d z i k r$ together, elderly gymnastics and so on. ${ }^{14}$

\section{OBSTACLES}

In implementing the Qoryah Thayyibah program, the obstacles faced by 'Aisyiyah Ponorogo include the incomplete work of several Qoryah Thayyibah fields, such as in law and politics, cultural arts, technology, and information. It is due to the fact that those five areas are still optimized 
by the concentration of the Qoryah Thayyibah program in Ponorogo. There are three regions where it has not been applied at all, but it has become a long-term strategy, and the next agenda instead since Qoryah Thayyibah's goal is solving critical problems occurring in the target village. The above five areas are crucial concerns that need to be addressed immediately.

While these three fields were not explicitly incorporated, they were indirectly included in other initiatives. In the area of law and politics, for instance, the socialization of domestic abuse (Domestic Violence) and its laws. Second, to offer support to people who are persecuted in order to uphold justice in community life. Third, creating a life that gives peace priority. Fourth, cultivating, with shared regard for fellow family members, a democratic environment. Fifth, according to the option of conscience, to increase confidence in expressing views and exercising political rights. These five items, such as religious tausiyah and social events, have been included on numerous occasions.

Other problems are in developing Islamic Cultural Arts as the area of cultural arts, reviving Indonesia's noble tradition, which does not contradict the ideals of Islamic teachings, urging individuals to be conscious of using art as a way of preaching. 'Aisyiyah has appealed to the Qoryah Thayyibah participants on these items and has been practiced under 'Aisyiyah in schools.

The area of information and technology by strengthening society from the detrimental effects of the independence of information technology. Secondly, to increase collaboration between members of the society to reduce the negative effects of freedom of information technology, such as crime and pornography. In many seminars and outreach conducted by 'Aisyiyah, these two points have been discussed.

During the Covid 19 pandemic, the key challenges faced by the Board of 'Aisyiyah Ponorogo in the implementation of Qoryah Thayyibah programs were the termination of many regular operations, insufficient room for' Aisyiyah related to the acquisition of member associations. However, by complying with health guidelines and reducing the frequency of in-person meetings, 'Aisyiyah is innovatively searching for 
better ways to execute her services. The problems that existed under normal circumstances in general (before the pandemic) are summarized in the table below:

\begin{tabular}{|c|c|c|}
\hline $\begin{array}{c}\text { Qoryah Thayyibah's Field of } \\
\text { Work }\end{array}$ & Type of activity & Obstacles \\
\hline Spirituality & $\begin{array}{l}\text { Da'wa bil-lisan } \\
\text { regularly every month }\end{array}$ & $\begin{array}{l}\text { The absence of some participants, } \\
\text { especially farmers, during the } \\
\text { planting and harvest season. Other } \\
\text { participants in the Javanese } \\
\text { walimah season (Month of Sha'ban, } \\
\text { Shawwal and Dzulhijjah). }\end{array}$ \\
\hline Economy & Entrepreneurial training & $\begin{array}{l}\text { There is no capital to build acquired } \\
\text { entrepreneurship skills for } \\
\text { participants, and no training in } \\
\text { product marketing management has } \\
\text { been held. }\end{array}$ \\
\hline Education Sector & $\begin{array}{l}\text { Training on literacy and } \\
\text { provision of reading } \\
\text { garden }\end{array}$ & $\begin{array}{l}\text { Low interest from members in } \\
\text { learning. }\end{array}$ \\
\hline health sector & $\begin{array}{l}\text { Organizing } \\
\text { offices/posts consulting } \\
\text { on reproductive health }\end{array}$ & $\begin{array}{l}\text { There is no special location that is } \\
\text { close and convenient for members } \\
\text { to enter. Still in 'Aisyiyah } \\
\text { Ponorogo Hospital, centered. }\end{array}$ \\
\hline Social Field & $\begin{array}{l}\text { Zakat, infaq and } \\
\text { sadaqah assistance }\end{array}$ & $\begin{array}{l}\text { There has not been a successful } \\
\text { way to create productive zakat for } \\
\text { members, even in the form of } \\
\text { disposable assistance. There is no } \\
\text { sort of assistance that offers } \\
\text { benefits that are sustainable. }\end{array}$ \\
\hline
\end{tabular}

Table 2. The Qoryah Thayyibah Ponorogo Program Obstacles

\section{ANALYSIS}

The purpose of Qoryah Thayyibah, in general, is to establish an Islamic society that is advanced and dignified. This program is still focused on the initial departure of the Qoryah Thayyibah from the Sakinah family. The aim to be accomplished is the physical and mental development of strong community groups, the creation of a healthy, peaceful and productive 
community environment and the realization of Al-Ma'un's preaching in the community.

A special and creative way of preaching is Qoryah Thayyibah. This software leads to a certain village that seeks to alter the importance of the village at once in different areas of existence. Qoryah Thayyibah is the solution to the preaching approach that is needed today because it addresses issues as a whole and comprehensively in society, not focusing on one side of the lives of people.

Qoryah Thayyibah is based on Brand Community Value, a model of preaching. Brand Community because it is a social group with a dedication to an association or initiative (being a community) that has a bond of solidarity. ${ }^{15}$ The value behind the Qoryah Thayyibah Community Brand is the actualization of the values of Muhammadiyah teachings, namely QS. Al-Ma'un and QS. Ali Imron 104. A movement that is oriented towards transformative theology, which consists of hablun minallah and hablun minannas as well as human obligations to uphold Amar Ma'ruf Nahi Munkar. With these values, it is hoped that Qoryah Thayyibah can answer the demands of society and be able to solve the problems they face concretely.

Spirituality or faith is the main field that is the focus of Qoryah Thayyibah preaching since real monotheism contributes to an understanding of Muslims. The realization that Allah is the Creator and encourages the belief that none of the creations of God were made in vain. This is what inspires Muslims to take advantage of His mercy, decorate their days of devotion to Him and fulfill their duties to become His caliph on this earth. ${ }^{16}$ The opportunity offered by Allah in the form of justification is best used to study His verses and improve them for the good of the people.

People will recognize the meaning of their existence in this world beginning from the true basis of tawhid. One of the main aspects is the right interpretation of the meaning of happiness (sa'adah). He understands what needs to be done and sought. Important happiness, according to Al-Attas, should be heart-oriented, to self-belief in the right of Ta'ala and the harvesting of activities based on that belief that is 
performed by oneself. So, the fruit of knowledge is ma'rifatullah. Information that can lead individuals to the idea that there is no god but Allah. This is the science of civilization and happiness that will lead people to. ${ }^{17}$

A culture is a result of the accumulation of three essential elements, according to Ibn Khaldun, namely: 1. The human capacity for thinking that creates science and technology, 2. In the shape of political and military force, the capacity to mobilize and 3 . The potential to struggle for life. ${ }^{18}$ Thus, the education sector is the primary asset of science and technology development. An efficient economy, physical and environmental health, food security, healthy and peaceful social environments and so on are the foundation of the capacity to fight for life.

In addition, the health sector is an area of work on Qoryah Thayyibah since several factors affect public health conduct, including beliefs (religion), values, expertise, knowledge and abilities, and the culture of both individuals and families. In the table below, these factors can be described:

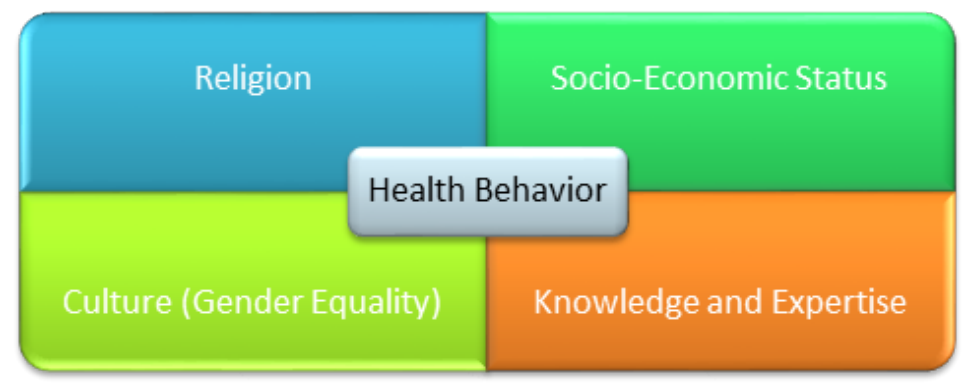

Picture 2. Factors influencing actions in public health

Religion is a significant foundation for directing actions in person or community health. Religion is a central principle that affects individuals and society's philosophy of life, the conception of health and illness by society, forms of food eaten, birth and death rites, and health care methods. A society with a huge effect on the prevention and treatment of health conditions will also influence religion. Islam, Christianity, Hinduism, for instance, have many laws surrounding food restrictions. ${ }^{19}$ 
In a family, women in the household have a food-related jobs. So, if aimed at mothers, environmental health and hygiene initiatives are very suitable. They will be aware of the value of safe and nutritious food, which will have a positive effect on the health of members of the family. It will also promote good nutritional status in children and prevent stunting. Not to mention that fertility concerns are frequently ignored, so if any difficulties are found, the presence of therapy in this regard will make women aware of the importance of protecting them and being sensitive.

Qoryah Thayyibah is a special and creative way of preaching, another case in the social sector since it does not incorporate all mothers of all ages into one association. By establishing Geriartri 'Aisyiyah, which had 70 elderly mothers as members, Qoryah Thayyibah distinguished her own elderly group. Considering that the needs of the elderly are also distinct from the needs of women at other ages, they are distinguished. It is definitely unnecessary to have adequate and in-depth Muhammadiyah materials for the elderly who have physical and psychological problems. The Elderly Group provides only light materials, and the distribution method is versatile and gentle. For example, how to perform dzikr and correct worship procedures is taught, special elderly gymnastics and other light activities are conducted. This is evidence that 'Aisyiyah attempted to pursue the way of preaching of the prophet, namely to change the purpose and meaning of the da'wa at hand. ${ }^{20}$ Thus, to decide the form of da'wa to be implemented, it is very important to look at the social circumstances, the character of mad' $u$, the prevalent customs.

Finally, the researcher suggested that how 'Aisyiyah would strengthen Muslims from the effects of modernity, globalization, and the development of communication technologies is what needs to be the subject of further preaching. ${ }^{21}$ Taking advantage of the advancement of information technology to become a strategic medium for da'wa. Da'wa must be rational, free (not coercive) and universal, as stated on QS. Al-Baqarah (2): 256, QS. Al-Kahf (18): 29 and QS. Shad (39): 41. 


\section{CONCLUSIONS}

This research found that the Qoryah Thayyibah Ponorogo Regional Management Program has been well implemented in the field of spirituality, education, social, economic and health, as well as the environment, in accordance with the Ponorogo community context. Nevertheless, in order to achieve the goal of Qoryah Thayyibah in creating physically and spiritually strong community groups, a safe, peaceful and prosperous community atmosphere, and realizing the al-ma'un da'wa movement in the community, the Regional Leaders of 'Aisyiyah Ponorogo need to create a new and innovative da'wa strategy and keep up with the advancement of information and technology. Second, the Regional Leaders of 'Aisyiyah Ponorogo should solve the obstacles by cooperating with relevant parties to achieve Qoryah Thayyibah's goals optimally.

\section{ACKNOWLEDGEMENT}

The highest appreciation is for the Regional Board of 'Aisyiyah Ponorogo and the Ministry of Science and Technology, in particular, who have assisted this research.

\section{ENDNOTES}

1 A. Muis, Komunikasi Islam (Bandung: Remaja Rosdakarya, 2001), p. 306-307. Andy Dermawan, "Landasan Epistemologi Ilmu Dakwah" dalam 2 Sukriyanto AR dkk., Metodologi Ilmu Dakwah (Yogyakarta: LESFI, 2002), p. 71-73.

3 Normative da'wa, namely Islamic preaching originating from the Al-Qur'an and Sunnah which is studied systematically-dialectically so that its moral teachings can be captured completely without reducing both. Historical da'wa is Islamic preaching that developed after the Prophet Muhammad. died until now, which is used as a reference and consideration to understand the two sources, namely the Al-Qur'an and Sunnah. The characteristics of this historical preaching are that it is always open to accept change, is in a scientific area that is ready to be tested for its scientific level, provides meaning and re-understanding of the existing reality of preaching. Da'wa is considered a process. See: Andy Dermawan, "Landasan Epistemologi..., p. 70-71.

4 Adaby Dahlan (dkk), 'Aisyiyah dan Sejarah Gerakan Perempuan Indonesia: Sebuah Tinjauan Awal (Yogyakarta: Jurusan Sejarah, Fakultas Humaniora UGM, 2010), p. 17-19. 
5 Pimpinan Pusat 'Aisyiyah, Sejarah Pertumbuhan dan Perkembangan 'Aisyiyah, (Jogjakarta: Seksi Khusus Penerbitan Pimpinan Pusat 'Aisyiyah, tt), p. 29.

6 Khofifah Indar Parawansa, Mengukir Paradigma Menembus Tradisi (Jakarta: LP3ES, 2006), p. ix.

7 As an initial implementation of the Qaryah Thoyyibah concept, 'Aisyiyah has conducted a trial in Mertosanan Wetan Hamlet, Potorono, Banguntapan, Bantul in 1989. The result of this trial is a composition of the Guidelines for the Implementation of Qaryah Thoyyibah which will be used as a guide for all regions of Indonesia. There are already 7 regional leaders of 'Aisyiyah who have assisted villages as the actualization of the concept of Qaryah Thayyibah. See: Ai Fatimah Nur Fuad, The Islamists' Responses to Modernity and Their Notion of Active Da'wa, Afkaruna Journal Vol. 15 No.02 Desember 2019, p. 194, PP 'Aisyiyah, Sejarah Pertumbuhan...,,p. 57.

8 The specific objective of Qaryah Thayibah is to increase the integration of organizational movements in an integrated manner, across assemblies, simultaneously from all organizational elements in 'Aisyiyah and other autonomous organizations in the Muhammadiyah organization to carry out da'wa amar makruf nahi munkar to empower the community. Second, accelerating efforts to carry out the revitalization of branches / branches in mobilizing all leaders of 'Aisyiyah organizations throughout Indonesia through various activities carried out across assemblies so that the existing da'wa develops and can move the community to be independent, advanced and dignified. Third, develop 'Aisyiyah da'wa in society with various development efforts, both through developing concepts and methods of preaching as well as developing da'wa targets in various parts of the country and abroad. See: Pimpinan Pusat 'Aisyiyah, Panduan Teknis Pelaksanaan Program Qaryah Thayibah (Yogyakarta: Pimpinan Pusat 'Aisyiyah, 2012), p. 13-14.

9 Ibid., p. 31-32.

10 The form of da'wa varies depending on the object at hand. For example, if the object of preaching is the disbelievers, the first call is to call them to believe in Allah SWT. And another pillar of faith. However, if the object of preaching is a Muslim, what will be conveyed is a call to implement Islamic teachings in all aspects of life and fight for Islam. See: Uswatun Ni'ami, Aktualisasi Dakwah di Era Globalisasi (Dalam Menegakkan Syariat Islam) in the journal Ulul Albab Volume 07 Number 02 June 2020. p. 54.

11 The figure we interviewed was the head of PDA Ponorogo $\mathrm{Hj}$. Titi Listyorini, S. H, Hj. Siti Khoirul Djannah, person in charge of Qoryah Thayyibah for East Java, Mrs. Ir. Hj. Siti Asfiyah, MKP and several other Qoryah Thayyibah administrators.

12 'Aisyiyah facilitates the process of syahadat (converting to Islam) and is ready to assist converts to understand and deepen Islam. Among them recorded in 
the official Ponorogo PDA news is the procession of a female figure in the Sooko sub-district, a junior high school teacher named Mamik Sri Budiarti who was previously a Christian. See: http://ponorogo.aisyiyah.or.id/berita /pengislaman-tokoh-wanita-kristen-ponorogo.html. accessed on 24 October 2020.

13 http://ponorogo.aisyiyah.or.id/id/berita/pelatihan-qoryah-thoyyibah.html. accessed on 20 October 2020.

14 http://ponorogo.aisyiyah.or.id/id/berita/launching-griya-lansia-sakinah-ais yiyah-ponorogo.html. accessed on 14 October 2020.

15 Muniz and O'Guinn revealed 3 important elements that underlie the community, namely awareness of the kind, which refers to the intrinsic relationship and collective feelings among members, as well as to feel differences with those who are not part of the community. Second, rituals and traditions (Rituals and Tradition) aim to maintain the cultural traditions of the community. Third is a sense of responsibility (Moral Responsibility), community members have a moral responsibility that must be maintained. See: Jr. A.M. Muniz And T.C. O'Guinn, Brand Community, Journal of Consumer Research, Vol. 27, No. 4 (2001), p. 412-432.

16 The aim is to make a Muslim truly a believer, Muslim and muhsin, that is, who can realize faith, Islam and ihsan in everyday life. Faith that can be brought in an attitude of how to get along with others and nature, faith that can respond to problems faced by the ummah. Tauhid Nur Azhar, Alam, Sains dan Teknologi (Solo: Tinta Medina, 2012), p. 208; Gusman Lesmana, Strategy for Developing Quality of Da'wa of Youth Muhammadiyah with Guidance and Counseling Service in the journal Biblio Cons Volume 2, no. 02 July 2019, p. 65.

17 Adian Husaini, Membendung Arus Liberalisme di Indonesia (Jakarta: Pustaka Al-Kautsar, 2009), p. 397-399.

18 Hamid Fahmy Zarkasyi, Worldview Islam Asas Peradaban (Jakarta: INSISTS, 2011), p.15-35.

19 Tri Hastuti Nur et al., Rumah Gizi 'Aisyiyah: Komunikasi Kesehatan dengan Pendekatan Agama-Budaya in the journal Global Communication Vol 9, No. June 1, 2020, p. 155-156.

20 The Prophet adjusted the methods and materials of preaching according to his object. The preaching period of Mecca, namely before the hijrah, was a period of composing the power of preaching which was carried out orally and addressed to the Prophet's family and members of his tribe. Da'wa material focuses on issues of faith. While in the Medina period the material of the Prophet's da'wa on social and state issues. See: Faiqotul Mala, Mengkaji Tradisi Nabi Sebagai Paradigma Dakwah Yang Ramah in the journal Dakwatuna Volume 6 Number 1 February 2020, p. 114; Mohammad Arif, Implementasi Dakwah Rasulullah Dalam Era Milenium in the journal Asketik 
Volume 4 Number 1 July 2020, p. 120-124.

21 The negative impact of modernization for Muslims is very significant, including the domination of the West, Islam which is increasingly marginalized and even excluded from politics and government and other consequences such as freedom that transcends boundaries and the distance of Muslims from Islam itself. The consequences of advancing science and technology not only lead to progress but have negative consequences, such as the threat of natural sustainability, depletion of natural resources and the threat of human existence and integrity. See: AI Fathimah Nur Fuad, The

22 Islamists' Responses..., p. 189-190.

Sulhan Hamid A. Ghani, Problematika Dakwah Islam Dalam Masyarakat Pluralis in the journal Paradigma, Volume 9, No. April 1, 2020, p. 2-3.

\section{REFERENCES}

Arif, Mohammad. Implementasi Dakwah Rasulullah Dalam Era Milenium in the journal Asketik Volume 4 Number 1 July 2020

Azhar, Tauhid Nur. 2012. Alam, Sains dan Teknologi. Solo: Tinta Medina.

Pimpinan Pusat 'Aisyiyah. tt .Sejarah Pertumbuhan dan Perkembangan 'Aisyiyah. Jogjakarta: Seksi Khusus Penerbitan Pimpinan Pusat 'Aisyiyah. 2012. Panduan Teknis Pelaksanaan Program Qaryah Thayibah. Yogyakarta: Pimpinan Pusat 'Aisyiyah.

Dahlan, Adaby (et al). 2010. 'Aisyiyah dan Sejarah Gerakan Perempuan Indonesia: Sebuah Tinjauan Awal. Yogyakarta: Jurusan Sejarah, Fakultas Humaniora UGM.

Damis, Rahmi. Research on the effectiveness of the Tabligh'Aisyiyah Council Study in improving the Community 's religious understanding. A study in Al-Fikr journal, volume 16, number 2, 2012.

Dermawan, Andy. 2002. "Landasan Epistemologi Ilmu Dakwah" dalam Sukriyanto AR dkk., Metodologi Ilmu Dakwah. Yogyakarta: LESFI.

Fuad, AI Fathimah Nur. The Islamists' Responses to Modernity and Their Notion of Active Da'wa in AFKARUNA Journal Volume 15 No. December 2, 2019.

Ghani, Sulhan Hamid A. Problematika Dakwah Islam Dalam Masyarakat Pluralis in the journal Paradigma, Volume 9, No. April 1, 2020.

http://ponorogo.aisyiyah.or.id/id/berita/launching-griya-lansia-sakinah-aisyiya h-ponorogo.html. accessed on 14 October 2020

http://ponorogo.aisyiyah.or.id/id/berita/pelatihan-qoryah-thoyyibah.html. accessed on 20 October 2020.

http://ponorogo.aisyiyah.or.id/id/berita/pengislaman-tokoh-wanita-kristen-p onorogo.html. accessed on 24 October 2020. 
Husaini, Adian. 2009. Blocking the Flow of Liberalism in Indonesia. Jakarta: Pustaka Al-Kautsar.

Lesmana, Gusman. Strategy for Developing Quality of Da'wa of Youth Muhammadiyah with Guidance and Counseling Service in the journal Biblio Cons Volume 2, no. 02 July 2019.

Mala, Faiqotul. Mengkaji Tradisi Nabi Sebagai Paradigma Dakwah Yang Ramah in the journal Dakwatuna Volume 6 Number 1 February 2020.

Muis, A. 2001. Komunikasi Islam. Bandung: Remaja Rosdakarya.

Muniz, Jr. A.M. And T.C. O'Guinn, Brand Community, Journal of Consumer Research, Vol. 27, No. 4 (2001)

Nata, Abuddin. 2002. Methodology of Islamic Studies. Jakarta: Raja Grafindo Persada.

Ni'ami, Uswatun. Aktualisasi Dakwah di Era Globalisasi (Dalam Menegakkan Syariat Islam) in the journal Ulul Albab Volume 07 Number 02 June 2020

Nur, Tri Hastuti., et al., Rumah Gizi 'Aisyiyah: Komunikasi Kesehatan dengan Pendekatan Agama-Budaya in the journal Global Communication Vol 9, No. June 1, 2020

Parawansa, Khofifah Indar. 2006. Mengukir Paradigma Menembus Tradisi. Jakarta: LP3ES.

Rohmah, Nur Laili. The 'Aisyiyah Malang Regional Organization 1968-1995 Research on the Women's Movement. A thesis compiled in 2010. at Malang State University, Historical Science Study Program

Salman, Ismah. The Organizational Role of Aisyiyah among Members in Creating Sakinah Families. A thesis written in the Women's Studies program at the University of Indonesia in 1995

Wuryaningtyas, Retno. The Struggle of Nyai Ahmad Dahlan to improve the role and position of women in 1914-1946 through 'Aisyiyah. A thesis compiled at the University of Indonesia, Faculty of Cultural Sciences, in 1999.

Zarkasyi, Hamid Fahmy. 2011. Worldview Islam Asas Peradaban. Jakarta: INSISTS. 